\title{
MicroRNAs' Gene Expression Technology for the Evaluation of Disease Modulation by Mild Nutrients
}

\author{
Farid E Ahmed ${ }^{1}$, Mostafa M Gouda ${ }^{2,3}$, Laila Hussein ${ }^{2}$, Paul W Vos ${ }^{4}$, Mohamed Mahmoud ${ }^{5}$, and
}

Nancy C Ahmed ${ }^{1}$

${ }^{1}$ GEM Tox Labs, Institute for Research in Biotechnology, 2905 South Memorial Drive, Greenville, NC 27834, USA.

${ }^{2}$ Department of Nutrition \& Food Science, National Research Center, El-Bohooth Street, Dokki, Cairo, Egypt

${ }^{3}$ National Research and Development Center for Egg Processing, College of Food Science and Technology, Huazhong Agricultural University, Wuhan, Hubei, PR, China

${ }^{4}$ Department of Biostatistics, College of Allied Health Sciences, East Carolina University, 600 Moye Boulevard, Greenville, NC 27858, USA

${ }^{5}$ USDA/ARS Children's Nutrition Research, 1100 Bates Street, Houston, TX 77030, USA

Received: June 19, 2018; Accepted: July 12, 2018; Published: July 21, 2018

*Corresponding author: Farid E Ahmed, GEM Tox Labs, Institute for Research in Biotechnology, 2905 South Memorial Dr, Greenville, NC 27834, USA, Tel. 252-375-9656, E-mail: gemtoxconsultants@yahoo.com

\begin{abstract}
This article demonstrates the use of melt curve analysis (MCA) for the interpretation of mild nutrogenomic micro (mi) RNA gene expression data, by measuring the magnitude of the expression of key miRNA molecules in stool of healthy human adults, used as molecular markers in excrements, following the intake of polyphenolrich Pomegranate juice (PGJ), functional fermented sobya (FS), which is rich in potential Probiotic lactobacilli, or their combination. Total small RNA was isolated from stool of 25 volunteers before and following a three week dietary intervention trial. Expression of 88 miRNA genes was evaluated using Qiagen's 96 well plate RT2 miRNA qPCR arrays. Employing parallel coordinates plots, no significant separation for the gene expression (C q) values was observed using Roche $480 \AA$ PCR Light Cycler instrument used in this study, and none of the miRNAs showed significant statistical expression after controlling for the false discovery rate. On the other hand, melting temperature profiles produced during PCR amplification run, found seven significant genes (miR-184, miR-203, miR-373, miR-124, miR96, miR-379 and miR-301a), which separated candidate miRNAs that could function as novel molecular markers of relevance to oxidative stress and immunoglobulin function, for the intake of polyphenol (PP)-rich, functional fermented foods rich in lactobacilli (FS), or their combination. We elaborate on these results, and present a detailed review on use of melt curves for analyzing nutigenomic miRNA expression data, which initially appear to show no significant expressions, but are actually more subtle than this simplistic view, necessitating the appreciation of the important role of MCA for a comprehensive understanding of what the collective expression and MCA data collectively imply. We have correlated miRNA genes with messenger (m) RNA genes using bioinformatics' methods.
\end{abstract}

Key Words: biomarkers, DNA, melt curve, fermented sobya miRNA, pomegranate, PCR, RNA

\section{Introduction}

\section{Gene expression and its control by miRNAs}

Cell's gene expression profile determines its function, phenotype and cells' response to external stimuli, and thus helps elucidate various cellular functions, biochemical pathways and regulatory mechanisms [1]. Several gene expression profiling methods at the mRNA level have emerged during past years, and have been successfully applied to cancer research. Profiling by microarrays [2,3] allows for the parallel quantification of thousands of genes from multiple samples simultaneously, using a single RNA preparation, and has become valuable because microarrays are convenient to use, do not require large-scale DNA sequencing, gives a clear idea of cells' physiological state, and is considered a comprehensive approach to characterize cancer molecularly, as seen in studies on colon cancer [1-3].

Control of gene expression has been studied by miRNA molecules, a small non-coding RNA molecules (18-24 nt long), involved in transcriptional and post-transcriptional regulation of gene expression by inhibiting gene translation, and the discovery of this molecule resulted in a 2006 Noble Prize in Physiology \& Medicine to Andrew Z Fire and Caraig C. Menlo for their work on RNA interference (RNAi) [https://science.howstuffworks. com/environmental/conservation/issues/nobel-prize-rnai. $\mathrm{htm}]$. MiRNAs silence gene expression through inhibiting mRNA translation to protein, or by enhancing the degradation of mRNA. Since first reported in 1993 [4], the number of identified miRNAs in June 2014, version 14.0, the latest miRBase release (v20) [5] contains 24,521 miRNA loci from 206 species, processed 
to produce 30,424 mature miRNA products. MiRNAs are processed by RNA polymerase II to form a precursor step which is a long primary transcript. Pri-miR is converted to miRNA by sequential cutting with two enzymes belonging to a class of RNA III endonuclease, Drosha and Dicer. Drosha converts the long primary transcripts to $\sim 70 \mathrm{nt}$ long primary miRNAs (pri-miR), which migrate to the cytoplasm by Exportin 5, and converted to mature miRNA ( 22 net) by Dicer [6]. Each miRNA may control multiple genes, and one or more miRNAs regulate a large proportion of human protein-coding genes, whereas each single gene may be regulated by multiple miRNAs [7]. MiRNAs inhibit gene expression through interaction with 3-untranslated regions (3 UTRs) of target mRNAs carrying complementary sequences [7]. Thus, the tumors had figured out a shrewed way to turn on the miRNAs, creating a growth process that is impossible to stop.

Effect of antioxidant polyphenols --abundant in Mediterranean diets-- on gene expression unraveled by the availability of molecular biology techniques, reveals our adaptation to environmental changes [8]. Efforts to study the human transcriptome have collectively been applied to tissue, blood, and urine (i.e., normally sterile materials), as well as stool (a non-sterile medium). Extraction protocols that employ commercial reagents to obtain high-yield, reverse-transcribable (RT) RNA from human stool in studies performed on colon cancer have been reported $[1,2,9]$

\section{Micro (mi) RNAs as biomarkers, and their roles in disease processes}

A biomarker is believed to be a characteristic indicator of normal biological processes, pathogenic processes, or pharmacological responses to therapeutic interventions [10, 11]. In contrast, clinical endpoints are considered as variables representing a study subject's health from his/her perspective [12-22]. A variety of biomarkers exist today as surrogates to access clinical outcomes in diseases, predict the health of individuals, or improve drug development. An ideal biomarker should be safe and easily measured, is cost effective to follow up, is modifiable with treatment, and is consistent across genders and various ethnic groups. Because we never have a complete understanding of all processes affecting individual's health, biomarkers need to be constantly reevaluated for their relationship between surrogate endpoints and true clinical endpoints [12-14]. MiRNAs have been used herein as biomarkers for assessing the effect of intake of PP-rich or fermented foods on the expression of 88 miRNA genes known to influence cancer.

\section{Disease modulation by nutrients}

Cardiovascular diseases due to hypercholesterolemia are considered a risk factor for Chronic Heart Disease (CHD), and chronic degenerative diseases --caused wholly or partially by dietary patterns-- represent the most serious threat to public health [23]. Moreover, nearly one-third of all cancer deaths are due to poor nutrition, lack of physical activity, and obesity; and these risk factors account for nearly $80 \%$ of large intestine, breast, and prostate cancers [24]. Chronic inflammation is considered a common factor that contributes to the development and progression of these illnesses, which are caused by and/or modified by diet [25].

Pomegranate juice (PGJ) and derived products are considered the richest sources of polyphenolic compounds [26], with positive implication on total serum cholesterol (TC), low-density lipoprotein cholesterol (LDL-C) and triglyceride (TG) plasma lipid profile [27]. Moreover, anthocyanin and ellagitannins pigments, mainly punicalagins, inhibit the activities of enzymes 3-hydroxy3-methylglutaryl-CoA reductase and sterol 0-acyltransferase, important in cholesterol metabolism [28]. Probiotic bacteria also contribute to lowering plasma hyper cholestrolemia due to the above mechanism, caused by the Probiotic bile salt hydrolases (BSH) activity. This Probiotic enzyme hydrolyses conjugates both glycodeoxycholic and taurodeoxycholic acids to hydrolysis products, inhibiting cholesterol absorption and decreasing reabsorption of bile acid [29].

Colonic micro biota is a central site for the metabolism of dietary PP and colonization of Probiotic bacteria. A dietary intervention study with Probiotic strains from three Lactobacillus species (L. acidophilus, L. casei and L. rhamnosus) given to healthy adults, showed that bacterial consumption caused the differential expression of from hundreds to thousands of genes in vivo in the human mucosa. The interaction of PP with the gut micro biota influences the expression of some human genes (i.e., nutritional transcriptomics), which mediates mechanisms underlying their beneficial effects [30]. Similar in vivo mucosal transcriptome findings have been reported when adults were given the Probiotic L. plantarum, illustrating how probiotics modulate human cellular pathways, and show remarkable similarity to responses obtained for certain bioactive molecules and drugs [31].

\section{Materials and Methods}

\section{Participants}

Study subjects were 25 healthy adults, 20 to 34 years old; exclusion was: absence of metabolic diseases, no use of medication for the last 6 weeks, and no signs of allergy or hypersensitivity to food or ingested material.

Exclusion criteria at the time of the screening were as follows: History of diabetes, hypertension, heart disease, or endocrine disorders; abnormal blood chemistry profile, fasting LDLcholesterol concentration $>3.37 \mathrm{~m} \mathrm{~mol} / \mathrm{L}(>130 \mathrm{mg} / \mathrm{d} \mathrm{L})$, or fasting triacylglycerol concentration $>3.39 \mathrm{mmol} / \mathrm{L}(>300 \mathrm{mg} /$ $\mathrm{dL}$ ), taking antioxidant or fish oil supplements. Female subjects were neither pregnant nor lactating. To minimize the potential confounding effects of consuming fluctuating amounts of foods and beverages that are high in dietary flavonoids, all subjects avoided the intakes of purple grapes, cocoa and chocolate during the entire three week dietary intervention trial. The volunteers were instructed to continue to eat their normal diet and not to alter their usual dietary or fluid intake with the exception of the previously mentioned food restrictions. 
Compliance with the supplementation in all subjects was satisfactory, as assessed daily, and all subjects continued their habitual diets throughout the study. The research protocol was approved by the institution review board at Egypt's NRC, and all subjects have given written consent prior to their participation in the study.

\section{Design of the study}

Figure 1 shows the design of the nutrigenomic randomized study. Estimated dietary intake was assessed by 3 repeated food records, one week before they were enrolled in the trial. The average portion sizes consumed, as well as composition data values from nutrient composition of the food were combined to assess average daily energy and nutrient intakes by the "nutrisurvey" software program. The characteristics of the voluntary subjects who were enrolled in the study, the mean daily energy intake, as well as selected macro nutrients are presented in Table 1.

\section{Isolate RNA $\rightarrow$ Reverse transcribe total RNA into cDNA $\rightarrow$ Carry out NGS or microarray studies $\rightarrow$ Analyze NGS or microaray data $\rightarrow$ Chose a smaller number of samples to run RT-qPCR reactions $\rightarrow$ Analyze quantitative PCR data}

Figure 1: miRNA Quantitation Experimental Workflow

Table 1: Composition of the supplements

\begin{tabular}{|c|c|c|c|c|c|}
\hline \multirow[t]{2}{*}{ Parameter } & \multirow[t]{2}{*}{ Unit } & \multicolumn{4}{|c|}{ Dietary supplements } \\
\hline & & $\begin{array}{c}\text { Control } \\
\text { (portion served) }\end{array}$ & $\begin{array}{c}\text { FS } \\
\text { (portion served) }\end{array}$ & $\begin{array}{c}\text { PGJ } \\
\text { (portion served) }\end{array}$ & FS+ PG (portionserved) \\
\hline Portion Size & $\mathrm{g}$ & - & 170 & 250 & $150+10$ \\
\hline Total Solids & $\mathrm{g}$ & - & 40.01 & 17.75 & 48 \\
\hline Carbohydrate & $\mathrm{g}$ & - & 51.10 & 32.75 & 59 \\
\hline Dietary Fiber & $\mathrm{g}$ & - & 54 & 0.25 & 48.6 \\
\hline Energy & kcal & - & 263 & 135 & 290 \\
\hline Lactobacillus & $\mathrm{cfu} /$ & - & & & \\
\hline Yeast & cfu/serving size & - & $2.77 \times 1010$ & - & $2.44 \times 1010$ \\
\hline Total PP & mg*/portion g & - & - & $519.1 \pm 8.75$ & $207.65 \pm 3.5$ \\
\hline Antioxidant & & - & & & \\
\hline activity & $(\mathrm{AEAC})^{* *}$ & - & $7.74 \pm 1.33$ & $11.35 \pm 2.2$ & $11.37 \pm 2.2$ \\
\hline
\end{tabular}

\section{Supplements}

Pomegranate was obtained in bulk from the Obour Public Market, Cairo, Egypt. Pomegranate fruits were peeled and the juice was extracted using a laboratory pilot press (Braun, Germany). The juice was distributed in aliquots of 100 or 250 grams in air tight, light-proof polyethylene bottles, and frozen at $-20^{\circ} \mathrm{C}$, where pomegranate polyphenols remained stable. Soursobya, a fermented rice porridge containing per gram $3 \times 10^{7} \mathrm{cfu}$ diverse lactic acid bacteria (LAB) and $1 \times 10^{7} \mathrm{cfu}$ Sacharomyces cerivisiae. With added ingredients such as milk, sugar and grated coconut, was purchased twice a week from the retail market, and saved in the refrigerator. Sobya is fermented rice. Table 2 illustrates the proximate initial and final mean urinary polyphenols, plasma and urinary ant oxidative activity, urinary thiobarbituric acid reactive species (TBARS), and erythrocytic glutathione-S-transferase (GS $\mathrm{T})$.

\section{Urine, blood and stool collection \& storage}

One day before starting the trial, urine and stool samples were collected from all volunteers, processed according to our standard operating methods, and saved frozen at $-70^{\circ} \mathrm{C}$.

Urine samples: Collection begins in the early morning after the subjects had fasted $10-12 \mathrm{~h}$ both on -1 , and $+21 \mathrm{~d}$ nutritional intervention and aliquots $(2 \mathrm{~mL})$ were immediately frozen at $-20^{\circ} \mathrm{C}$ for biochemical analysis.

Blood samples: Blood was drawn by vein-puncture and collected in sodium citrated tubes. The plasma was separated from blood cells by centrifugation at $3000 \mathrm{rpm}$ for $15 \mathrm{~min}$ at $4^{\circ} \mathrm{C}$ and the separated plasma was stored at $-70^{\circ} \mathrm{C}$ for later biochemical analysis. The red blood cells (RBCs) were washed using cold physiological saline solution and stored at $-20^{\circ} \mathrm{C}$. 
Table 2: Initial and final mean urinary polyphenols, plasma and urinary ant oxidative activity, urinary TBARS and erythrocytic GST

\begin{tabular}{|c|c|c|c|c|c|c|c|c|c|}
\hline \multirow{3}{*}{ Parameter } & \multirow{3}{*}{ Unit } & \multirow{2}{*}{\multicolumn{2}{|c|}{\begin{tabular}{|c|} 
Control \\
Baseline Final \\
\end{tabular}}} & \multirow{2}{*}{\multicolumn{2}{|c|}{\begin{tabular}{c|} 
Sobya \\
Baseline Final
\end{tabular}}} & \multirow{2}{*}{\multicolumn{2}{|c|}{$\begin{array}{c}\text { Pomegranate } \\
\text { Baseline Final }\end{array}$}} & \multirow{2}{*}{\multicolumn{2}{|c|}{$\begin{array}{c}\text { Sobya+Pomegranate } \\
\text { Baseline Final }\end{array}$}} \\
\hline & & & & & & & & & \\
\hline & & $\mathrm{X} \pm \mathrm{SE}$ & $\mathrm{X} \pm \mathrm{SE} p$ & $\mathrm{X} \pm \mathrm{SE}$ & $X \pm S E p$ & $\mathrm{X} \pm \mathrm{SE}$ & $\mathrm{X} \pm \mathrm{SE} p$ & $\mathrm{X} \pm \mathrm{SE}$ & $\mathrm{X} \pm \mathrm{SE} p$ \\
\hline Urinary & $\mathrm{GAE} / \mathrm{mg}$ & 10.36 & 8.11 & 11.84 & 9.86 & 5.70 & $\begin{array}{l}55.23 \\
<0.05\end{array}$ & 10.40 & 21.62 \\
\hline polyphenol & creat & \pm 1.8 & \pm 2.2 & \pm 6.2 & \pm 1.8 & \pm 1.4 & \pm 21.7 & \pm 3.2 & \pm 7.3 \\
\hline Urinary & $\mathrm{AEAC} / \mathrm{mg}$ & 9.74 & 8.13 & 3.89 & 10.30 & 7.18 & $\begin{array}{l}46.57 \\
<0.05\end{array}$ & 10.90 & 20.25 \\
\hline $\begin{array}{l}\text { antioxidant } \\
\text { activity }\end{array}$ & creat* & \pm 2.0 & \pm 2.7 & \pm 09 & \pm 2.3 & \pm 0.9 & \pm 18.0 & \pm 2.4 & \pm 3.9 \\
\hline Urinary & $\mathrm{ug} / \mathrm{mg}$ & 83.04 & 75.17 & 82.77 & 29.97 & 173.93 & $\begin{array}{l}51.48 \\
<0.05\end{array}$ & 157.70 & 40.62 \\
\hline TBARS & creat & \pm 12.1 & \pm 15.3 & \pm 27.8 & \pm 4.4 & \pm 44.8 & \pm 8.2 & \pm 47.8 & \pm 8.3 \\
\hline Plasma & $\mathrm{AEAC/}$ & 6.36 & 5.99 & 3.70 & 4.55 & 3.64 & $\begin{array}{c}5.92 \\
<0.05\end{array}$ & 2.78 & 4.49 \\
\hline antioxidant & $100 \mathrm{ml}$ & \pm 2.81 & \pm 2.66 & \pm 0.33 & \pm 0.27 & \pm 0.30 & \pm 0.68 & \pm 0.11 & \pm 0.58 \\
\hline E-GST & $\mathrm{IU} / \mathrm{g} \mathrm{Hb}$ & 5.94 & 5.45 & $\begin{array}{l}4.26 \\
<0.05\end{array}$ & 7.21 & 4.73 & 8.34 & 4.56 & 6.90 \\
\hline activity & & \pm 3.3 & \pm 4.1 & \pm 0.5 & \pm 0.8 & \pm 1.0 & \pm 1.0 & \pm 1.0 & \pm 1.0 \\
\hline
\end{tabular}

$\mathrm{X} \pm$ SE: Mean \pm Standard Error, ${ }^{*}: \mathrm{mmol}$ ascorbic acid equivalent antioxidant capacity/mg creatinine; GAE: gallic acid equivalent, Mean values are significantly different if the $\mathrm{P}$-values are less than $0,05(\mathrm{P}<0.05)[13]$.

Stool samples: Feces (excrement) were obtained from the 25 healthy adults, twice at day 0 and three weeks after the dietary intervention. All stools were collected with sterile, disposable wood spatulas in clean containers, after stools were freshly passed, and then placed for storage into Nalgene screw top vials (Thermo Fisher Scientific, Inc., Palo Alto, CA, USA), each containing $2 \mathrm{ml}$ of the preservative RNA later (Applied Biosystems/Ambion, Austin, TX, USA), which prevents the fragmentation of the fragile mRNA molecule [1], and vials were stored at $-70^{\circ} \mathrm{C}$ until samples were ready for further analysis. Total small RNA, containing miRNAs, was extracted from all frozen samples at once, when ready, and there was no need to separate mRNA containing small miRNAs from total RNA, as small total RNA was suitable daytracting small total RNA from stool was carried out using a guanidinium-based buffer, whand saved frozen atich comes with the RNeasy isolation Kit ${ }^{\circledR}$, Qiagen, Valencia, CA, USA, as we have previously detailed. DNase digestion was not carried out, as our earlier work demonstrated no difference in RNA yield or effect on RT-PCR after DNase digestion [1]. The time to purify aqueous RNA from all of the 25 frozen stool samples was $\sim$ three hours. Small RNA concentrations were measured spectrophotometrically at $\lambda 260 \mathrm{~nm}, 280 \mathrm{~nm}$ and $230 \mathrm{~nm}$, using a Nano-Drop spectrophotometer (Themo-Fischer Scientific). The integrity of total RNA was determined by an Agilent 2100 Bio analyzer (Agilent Technologies, Inc., Palo Alto, CA, USA) utilizing the RNA 6000 Nano Lab Chip®. RNA integrity number (RIN) was computed for each sample using instrument's software [1].

\section{Preparation of ss-cDNA for molecular analysis}

The $\mathrm{RT}^{2}$ miRNA First Strand Kit ${ }^{\circledR}$ from SABiosciences Corporation (Frederick, MD, USA) was employed for making a copy of ss-DNA in a $10.0 \mu \mathrm{l}$ reverse transcription (RT) reaction, for each RNA samples in a sterile PCR tube, containing $100 \mathrm{ng}$ total RNA, $1.0 \mu \mathrm{l}$ miRNA RT primer \& ERC mix, $2.0 / \mu$ l 5X miRNA RT buffer, $1.0 \mu \mathrm{l}$ miRNA RT enzyme mix, $1.0 \mu \mathrm{l}$ nucleotide mix and Rnase-free $\mathrm{H}_{2} \mathrm{O}$ to a final volume of $10.0 \mu$. The same amount of total RNA was used for each sample. Contents were gently mixed with a pipettor, followed by brief centrifugation. All tubes were then incubated for 2 hours at $37^{\circ} \mathrm{C}$, followed by heating at $95^{\circ} \mathrm{C}$ for 5 minutes to degrade the RNA and inactivate the RT. All tubes were chilled on ice for 5 minutes, and $90 \mu \mathrm{l}$ of Rnase-free $\mathrm{H}_{2} \mathrm{O}$ was added to each tube. Finished miRNA First Strand C DNA synthesis reactions were then stored overnight at $-20^{\circ} \mathrm{C}[1]$.

\section{Use of cancer $\mathrm{RT}^{2}$ miRNA PCR array 96-well plate to study miRNAs' expressions}

We used a SABiosciences $\mathrm{RT}^{2}$ miRNA qPCR Array Plate System for Human (Qiagen) to analyze miRNA expression using real-time, reverse transcription PCR (RT-qPCR) as a sensitive and reliable quantitative method for miRNA expression analysis. 
The arrays employ a SYBR Green real-time PCR detection system, which has been optimized to analyze the expression of many mature miRNAs simultaneously. Each 96-well array plate contains a panel of primer sets for 88 relevant miRNA focused pathways (one universal primer and one gene-specific primer for each miRNA sequence), plus four housekeeping genes (Human SNORD 48, 47 and 44, and U6), and two RNA and two PCR quality controls. Duplicate RT Controls (RTC) to test the efficiency of the miRNA RT reaction, with a primer set that detects the template synthesized from the built in miRNA External RNA Control (ERC).
There are duplicate RT controls (RTC) to test the efficiency of the miRNA RT process, with a primer set to detect the template synthesized from the kit's built-in miRNA External RNA Control (ERC). There is also duplicate positive PCR controls (PPC) to test the efficiency of the PCR process, using a per-dispensed artificial DNA sequence and the primer set that detects it. The two sets of duplicate control wells (RTC and PPC) also test for inter-well, intra-plate consistency. The human $\mathrm{RT}^{2}$ miRNA PCR Arrays reflect miRNA sequences annotated by the Sanger miRBase Release 14 . Figure 2 shows the layout of the MAH-102F array.

\section{Layout for Human cancer RT ${ }^{2}$ miRNA qPCR Array (MAH-102A)}

\begin{tabular}{|c|c|c|c|c|c|c|c|c|c|c|c|c|}
\hline & 1 & 2 & 3 & 4 & 5 & 6 & 7 & 8 & 9 & 10 & 11 & 12 \\
\hline A & let-7a & miR-133b & $m i R-122$ & $m i R-20 b$ & mir-335 & miR-196a & miR-125a-5p & miR-142-5p & miR-96 & miR-222 & miR-148b & miR-92a \\
\hline 3 & miR-184 & miR-214 & miR-15a & miR-18b & $m i R-378$ & let-7b & miR-205 & miR-181a & miR-130a & miR-199a-3p & $m i R-140-5 p$ & miR-20a \\
\hline c & miR-146b-5p & $m i R-132$ & miR-193b & miR-183 & miR-34c-5p & $\mathrm{miR}-30 \mathrm{c}$ & miR-148a & miR-134 & let-7g & miR-138 & miR-373 & let-7c \\
\hline o & let-7e & miR-218 & $m i R-29 b$ & miR-146a & $\mathrm{miR}-212$ & miR-135b & miR-206 & $m i R-124$ & miR-21 & miR-181d & miR-301a & mir-200c \\
\hline 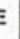 & miR-100 & $m i R-10 b$ & miR-155 & miR-1 & $\operatorname{miR}-363$ & miR-150 & let-7i & miR-27b & miR-7 & miR-127-5p & $m i R-29 a$ & miR-191 \\
\hline $\mathrm{F}$ & let-7d & miR-9 & let-7f & $m i R-10 a$ & miR-181b & miR-15b & miR-16 & $m i R-210$ & miR-106a/17 & miR-98 & miR-34a & miR-25 \\
\hline & miR-144 & miR-128a & miR-143 & miR-215 & miR-19a & miR-193a-5p & miR-18a & miR-125b & miR-126 & miR-27a & miR-372 & miR-149 \\
\hline H & miR-23b & miR-203 & miR-32 & miR-181c & SNORD48 & SNORD47 & SNORD44 & RNUG-2 & miRTC & miRTC & PPC & PPC \\
\hline
\end{tabular}

\section{Source: SABiosciemces, a Qiagen Company, Fredrick, Maryland, USA}

Figure 2: Array lay out for Qiagen's human cancer RT2 miRNA qPCR Plate Array (MAH-102A).

\section{Performing real-time quantitative polymerase chain reaction (qPCR)}

We used RT² SYBR Green qPCR Master Mix (SBA Biosciences) to obtain accurate results from our qPCR arrays. The following components were mixed in a 15-ml tube for 96-well plate format: $1275 \mu \mathrm{l}$ of $2 \mathrm{X} \mathrm{RT}^{2}$ SYBR Green PCR Master Mix, $100 \mu \mathrm{l}$ of diluted first strand reaction, $1175 \mu \mathrm{l}$ of $\mathrm{ddH}_{2} \mathrm{O}$ (total volume $2550 \mu \mathrm{l}$, of which 2400 was needed for 96 reactions, each well having $25 \mu \mathrm{l}$, with $150 \mu \mathrm{l}$ cocktail remaining.

We employed a Roche Light Cycler 480® 96-well block PCR Machine (Roche, Mannheim, Germany) to carry out quantitative real-time miRNA expressions. When ready, we removed the needed miRNA qPCR Arrays, each wrapped in aluminum foil, from their sealed bags, added $25 \mu \mathrm{l}$ of the same cocktail to each well, adjusted the ramp rate to $1^{\circ} \mathrm{C} / \mathrm{sec}$. We used 45 cycles in the program, and employed the Second Derivative Maximum method, available with the Light Cycler $480 \AA$ software for data analysis [32]. We first heated the 96 well plate for $10 \mathrm{~min}$ at $95^{\circ} \mathrm{C}$ to activate the Hot Start DNA polymerase, then used a three-step cycling program (a 15 seconds heating at $95^{\circ} \mathrm{C}$ to separate the ds DNA, a 30 seconds annealing step at $60 \mathrm{oC}$ to detect and record SYBR Green fluorescence at each well during each cycle, and a final heating step for 30 seconds at $72^{\circ} \mathrm{C}$ ). Each plate was visually inspected after the run for signs of evaporation from the wells. Data were analyzed using the $2-\Delta \Delta \mathrm{Ct}$ method [33]. Resulting threshold cycle values for all wells were exported to a blank
Excel sheet for analysis. We also ran a Dissociation (Melt) Curve Program after the cycling program [34], and generated a first derivative dissociation curve for each well in the plate, using the LC (Light cycler's ${ }^{\circledR}$ ) software.

Use of transcriptomic markers for colon cancer screening in stool, blood and tissue

Using molecular methods to carry out quantitative gene expression studies on stool, blood and tissue samples, allows for sensitive and specific routine monitoring and diagnostic screening of colon cancer at the early malignant tags for ten genes: HPRT, IGF2, FLNA, TGFßigh, CKS2, CSE1L, KLK10, CXCL3, GUCA2B, IL-12] in a two-step quantitative PCR end-point, on an Applied Bio system 9600 thermo cycler (Foster City, CA) on single-stranded (s s)-cDNA at $>90 \%$ sensitivity and $>95 \%$ specificity, using a master mix containing final concentrations of 1X Hugh fidelity PCR buffer, 0,2 mM dNTP, $2 \mathrm{mM} \mathrm{MgSO}{ }_{4}, 0.4 \mu \mathrm{m}$ forward and reverse primers, $0.1 \mathrm{ng}$ ss-cDNA template and $1 \mathrm{U}$ of "hot start" Platinum High Taq DNA polymerase (Invitrogen) in a final volume of $25 \mathrm{ul}$, in a $100 \mathrm{ul} \mathrm{PCR} \mathrm{tube.} \mathrm{Running} \mathrm{conditions}$ were: one cycle at $94^{\circ} \mathrm{C}$ for $3 \mathrm{~min}$ to activate the hot start Taq, 35 cycles of $94^{\circ} \mathrm{C}$ denaturation for $45 \mathrm{sec}, 55^{\circ} \mathrm{C}$ annealing for 1 min and $72^{\circ} \mathrm{C}$ elongation for $1 \mathrm{mimn}$, followed by one elongation/ extension cycle at $72^{\circ} \mathrm{C}$ for $7 \mathrm{~min}$. Reactions were placed in a well of a $1 \%$ agarose gel immersed with $1 \mathrm{X}$ Tris-acetate EDTA (TAE) gel running buffer in an electrophoresis apparatus (5 V per $\mathrm{cm})$, gel stained with ethedium bromide $(0.25 \mathrm{u} \mathrm{g} / \mathrm{ml}$ final 
concentration), and visualized using an Alpha Innotech chargecoupled device (CCD) based imaging system (San Leandro, CA). A semi-quantitative real-time PCR, which employed the comparative cross point (CP) method, also named E-method [36] was employed on a Roche's Light Cycler (LCTM) model 2.0 PCR using the LC Relative Quantification Software TM; which employs the LC Relative Quantification Software using standard curves in which standard concentrations are plotted versus the threshold cycle to calculate the unknown sample, without user input [3638], Figure 2 [1]. However, we later on employed the more stable miRNAs' genes, because miRNA molecules are more stable, and easier to handle and work with than the more fragile mRNA molecules. We have bioinformatically correlated the mRNA with miRNA genes using Target Scan algorithm, and employing the DAVID program [39].

\section{Role of biomarker miRNAs in various diseases}

MiRNA functions were shown to regulate development [35] and apoptosis [36], and dysregulation of miRNAs has been associated with many diseases such as various cancers [37], heart diseases [38], and kidney diseases [39]. Nervous system diseases [40], alcoholism [41], obesity [42], auditory diseases [43], eye diseases [44], skeletal growth defects [45], as well as key role in host-virus pathogenesis of viral diseases [46].A negative correlation was found between tissue specificity of interactions and miRNA in a number of diseases, and an association between miRNA conservation and disease, and predefined miRNA groups allow for identification of novel disease biomarkers at the miRNA level [47]. Specific miRNAs are crucial in oncogenesis [48], effective in classifying solid [49] and liquid tumors [50], and function as oncogenes or tumor suppressor genes [51]. MiRNA genes are often located at fragile sites, as well as minimal regions of loss of heterozygosity, or amplification of common breakpoints regions, suggesting their involvement in carcinogenesis [52]. MiRNAs have shown to serve as biomarkers for cancer diagnosis, prognosis and/or response to therapy [53, 54]. Profiles of miRNA expression differ between normal tissues and tumor types, and evidence suggests that miRNA expression profiles can cluster similar tumor types together more accurately than expression profiles of protein-coding messenger (m) RNA genes [55]. Besides, small miRNAs ( 18-22 nt long) are stable molecules than the fragile mRNA [56].

\section{Melt Curve analysis}

MCA has been an effective and economical way for identification of virus stains [57], genes [58], bacterial strains [59], insect species [60], temperature validation of PCR cyclers [61], detection of translocations in lymphomas [62] and RNA interference/gene silencing [63]. Thus, the presence of double peaks during MCA is not always indicative of nonspecific amplification, and other methods such as agarose gel electrophoresis and use of melt curve prediction software [64, 65] are also needed in odder to determine the purity of an amplicon. For example, Figure 5A shows a single peak for exon $17 \mathrm{~b}$ of CFTE
(Cystic Fibrosis Transmembrane Conductance Regulator) gene, whereas the melt curve for an amplicon from exon 7 of CFTR shows two peaks, which could be interpreted as indicative of two separate amplicons (Figure 5B). However, analysis by agarose gel electrophoresis showed only one peak. To solve this conflict, an understanding of how melt curves are produced is needed. It should be emphasized that intercalating dyes used in qPCR, such as SYBR Green, will fluoresce only when the dye is bound to ds DNA, but not in the presence of a ssDNA, or when the DNA is free in solution. After the amplification cycle in qPCR, the instrument starts at a preset temperature above the primer Tm, and as the temperature increases dsDNA denatures becoming ssDNA and the

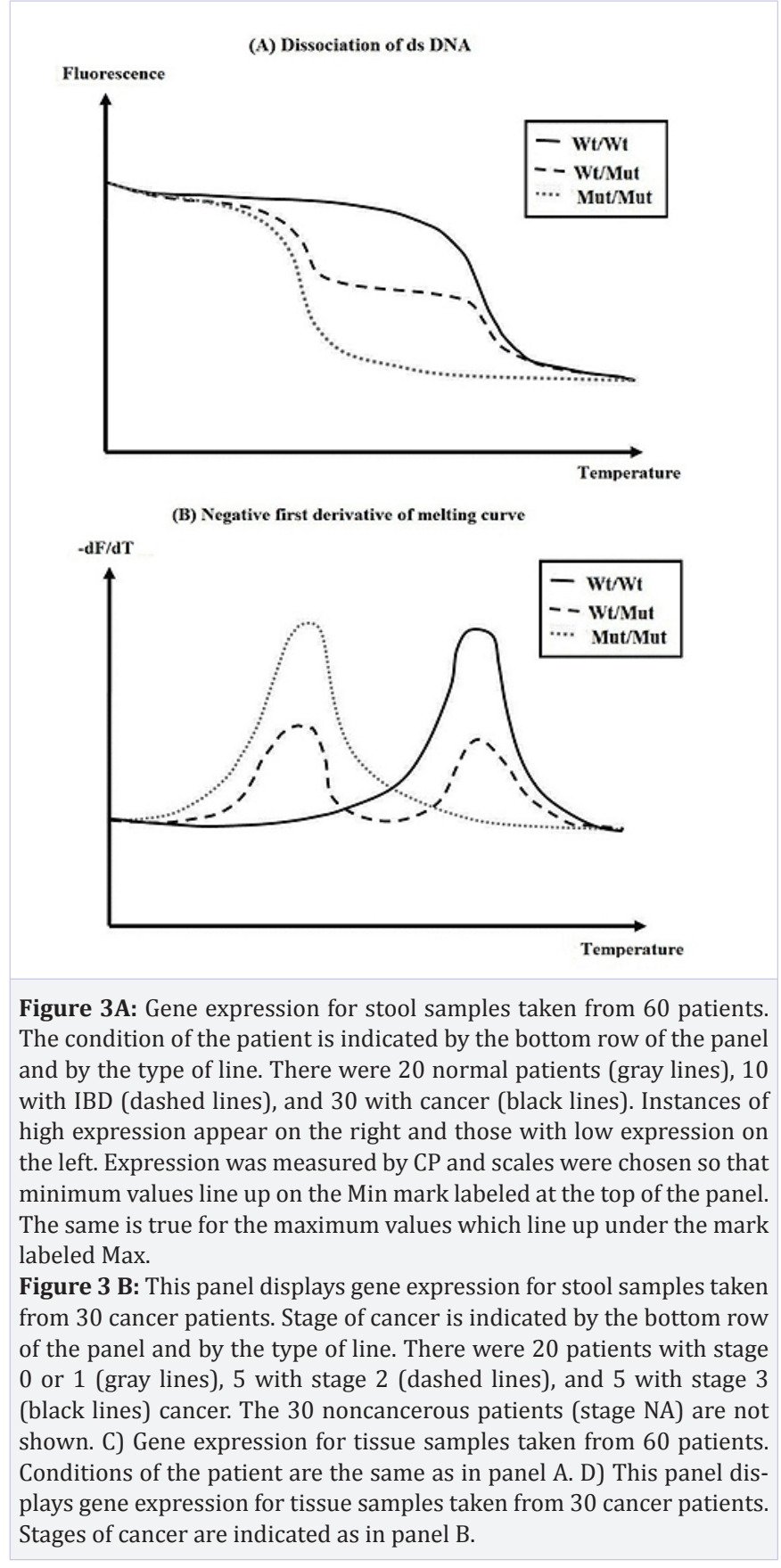



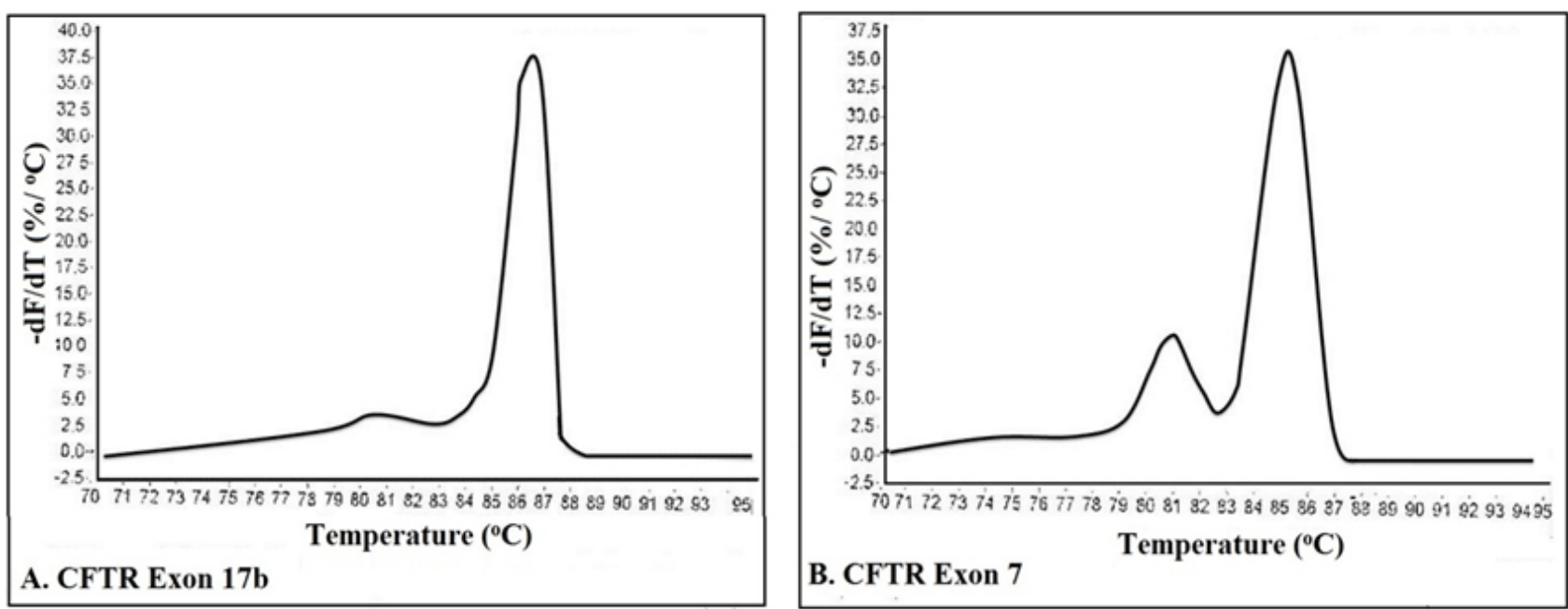

Figure 4A: Graph illustrating the relation between fluorescence and and temperature for labeled probe designed for a wild type (Wt) sequence, homozygous Wt, heterozygous(Wt/Mut), and homozygous mutant (Mut/Mut) combination.

Figure 4 B: Graph of the first derivative of melting curve (-df/dT) that pinpoints the temperature of dissociation, defined as $50 \%$ dissociation, by formed peaks. Figure courtesy of Integrated DNA Technologies (www.idtdna.com); Downey N. (2014) Interpreting melt curves: An indicator, not a diagnosis. [Online] Coralville, Integrated DNA Technologies. [Accessed May, 26, 2017]

(A)

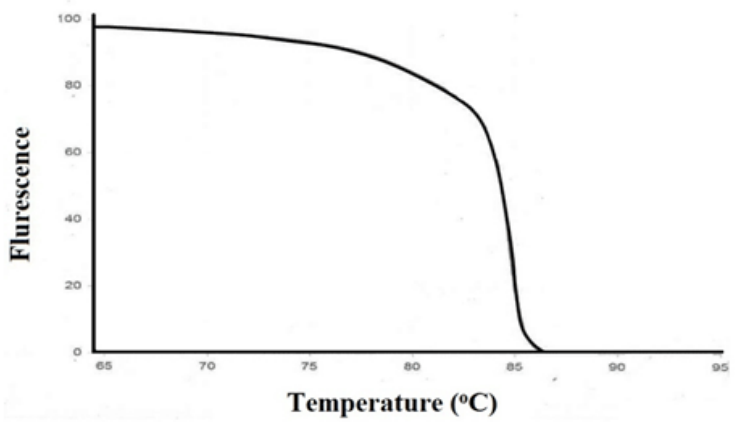

(B)

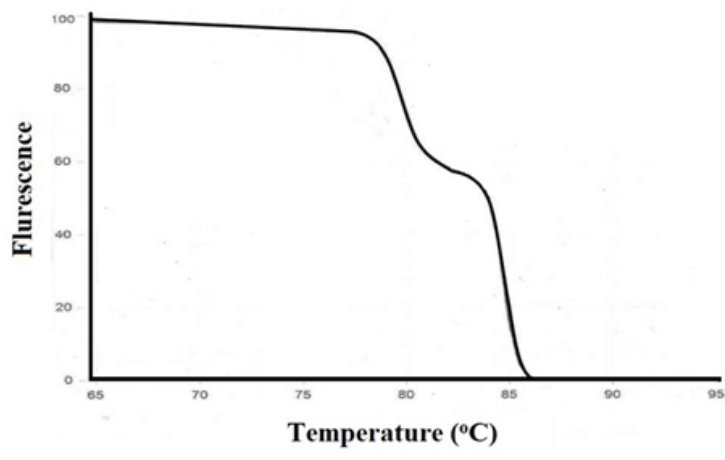

Figure 5A: Melt curves from qPCR of the CFTR ( Cystic Fibrosis Transmembrane Conductance Regulator)gene. A. An amplicon from CFTR exon $17 \mathrm{~b}$ reveals a single peak following melt curve analysis.

Figure 5B: An amplicon from CFTR exon 7 reveals two peaks. Figure courtesy of Integrated DNA Technologies (www.idtdna.com);Downey N. (2014) Interpreting melt curves: An indicator, not a diagnosis. [Online] Coralville, Integrated DNA Technologies. [Accessed May, 26, 2017] dye therefore dissociates from the ssDNA (Figure 3A). The change in slope of this curve when blotted as a function of temperature to obtain a melt curve for CFTR exom 17b (Figure 4A) However, if we allow for the possibility that DNA my assume an intermediate state that is neither dsDNA or ssDNA, raw date from CFTR exon 7 melt will look Figure 4B. This could happen when there are regions of the amplicon that are more stable (e.g., G/C rich), which do not melt immediately, but maintain their ds configuration until the temperature becomes sufficiently high to melt it, which results in two phases (Figure 4B). Additional sequence factors, such as amplicon misalignment in $\mathrm{A} / \mathrm{T}$ rich regions, and designs that have secondary structure in the amplicon region, can also produce products that melt in multiple phases.

An advancement of MCA, referred to as High Resolution Melt (HRM), discovered and developed by Idaho Technology and the University of Utah [66, http://www.dna.utah.edu/Hi-Res/TOP_ Hi-Res\%20Melting.html], which has been useful for mutation detection and SNPs, enabling differentiation of homozygous wildtype, heterozygous and homozygous mutant alleles from the dissociation patterns. HRM has been used to identify variation in nucleic acid sequences, enabled by use of a more advanced software, and is therefore less expensive than probe-based genotyping methods, and allows for identification of variants quickly and accurately [67]. This method has been widely used in molecular diagnosis and for detection of mutations [68-74].

MCA is an assessment of dissociation characteristics of dsDNA during heating, leading to rise in absorbance, intensity and hyperchromicity. The temperature at which $50 \%$ of DNA is denatured is referred to as melting point, Tm.

Gathered information can be used to infer the presence of single nucleotide polymorphism (SNP), as well as clues to 
molecule's mode of interaction with DNA, such as intercalator slots in between base pairs through pi stacking and increasing salt concentration, leading to rise in melt temperature, whereas pH can affect DNA's stability, leading to lowering of its melting temperature [75,76]. Originally, strand dissociation was measured using UV absorbency, but now techniques based on fluorescence measurements using DNA intercalating fluorophores such as SYBR Green I, Eva Green, or Fluorophore-labelled DNA probes (FRET probes) when they are bound to ds DNA [75] are now common. Specialized thermal cyclers that run the qPCR, such as Roche Light Cycler (LC) $480 \AA$, used in this study, is programmed to produce the melt curve after the amplification cycles are completed. As the temperature increases, dsDNA denatures becoming ss and the dye dissociates, resulting in decrease in fluorescence. The graph of the negative first derivative of the melting-curve $(-\mathrm{dF} / \mathrm{dT})$ represents the rate of change of fluorescence in the amplification reaction, and allows pin-pointing the temperature of dissociation ( $50 \%$ dissociation) using formed peaks to obviate or complement sequencing efforts [77].

The melting temperature (Tm) of each product is defined as the temperature at which the corresponding peak maximum occurs. The MCA confirms the specificity of the chosen primers, as well as reveals the presence of primer-dimers, which usually melt at lower temperatures than the desired product, because of their small size, and their presence severely reduce the amplification efficiency of the target gene as they compete for reaction components during amplification, and ultimately the accuracy of the data. The greatest effect is observed at the lowest concentrations of DNA, which ultimately compromises the dynamic range. Moreover, nonspecific amplifications may result in PCR products that melt at temperatures above or below that of the desired product. Optimizing reaction components (Mg2+, detergents, SYBR Green I concentration) and annealing temperatures aid in decreasing nonspecific product formation [78-80]. Adequate product design, however, is considered to be the best method to avoid nonspecific products' formation. Including a negative control will determine if there is a co amplified genomic DNA $[81,82]$. The formula for Tm calculation is shown by the equation:

$$
\mathrm{Tm}=\quad \ldots \Sigma \Delta \text { Hon-n } \quad---273.15, \underline{\Sigma} \Delta \mathrm{So}_{\mathrm{n}-\mathrm{n}}+\mathrm{RLnCT}
$$

where thermodynamic parameter $\Delta H o$ is Enthalpy changes, $\Delta$ So parameter is Entropy changes, and $\mathrm{C}_{\mathrm{T}}$ is total strand concentration; these free-energy parameters predict $\mathrm{T}_{\mathrm{m}}$ of most oligonucleotide duplexes to within $5^{\circ} \mathrm{C}$; and permit prediction of DNA, as well as RNA duplex stabilities. It should be noted that Tm depends on the conditions of the experiment, such as oligonucleotide concentration, salts' concentration, mismatches and single nucleotide polymorphisms (SNPs) [83]. OligoAnalyzer ${ }^{\circledR}$ Tool [www.idtdna.com/analyzer/Applications/Oligoanalyzer] allows for calculating the $\mathrm{T}_{\mathrm{m}}$ of employed nucleotides.

\section{Statistical and bioinformatics analysis}

Gene expressions were standardized by dividing the SNORD48 value while raw melting temperatures were used. Analysis were done using the software R (version 3.1.3), with the package MASS [84]. One individual had so many missing values that this case was not used in the analysis so that the number of individuals is 24. For each standardized gene and each melting temperature, a one way ANOVA was used to obtain a p-value. There were four levels of the explanatory variable: Control, Sobya, Pom, and Both. Parallel coordinate plots (parcoord command in R) [85] were used to visualize the data for each gene and each melting temperature. Coordinates were ordered using the magnitude of the p-value. The two sample t-test was used on gene expression to compare control to sobya and control to both (t.test command in $\mathrm{R}$ with var.equal=FALSE) [86]. P-values were adjusted to control for false discovery rate. The method is outlined in [87] Benjamini and Yekutieli (p.adjust command in R with method='BY').

We have bioinformatically correlated the 2-7 or 2-8 complement nucleotide bases in the mature miRNAs with the untranslated 3' region of target mRNA (3' UTR) of a message using a basic algorithm such as Broad's Institute's Target Scan [88] http://www.targetscan.org/archives.html, which provides a precompiled list for their prediction.

\section{Results}

At base line, all participants in the trial excreted urinary total polyphenols; however, the inter individual variation was considerably high (4.89-12.59 mg GAE/100 ml urine).

Composition of the three supplements (FS, PGJ and FS + PGJ served to the volunteers is presented in Table 1 . The initial and final mean urinary polyphenols, plasma and urinary ant oxidative activity, urinary TBARS and erythrocytic GST, as well as the daily portion of PGJ provided $21 \mathrm{mg}$ PP /day, and the combination of PGJ - FS was $9 \mathrm{mg}$ PP /day, as presented in Table 2.

Figure 2 is a layout of $\mathrm{RT}^{2}$ miRNA PCR Array Human Cancer microRNA (MAH-102A). Figure 6 is a graphical representation of the parallel plot coordinates of the studied miRNA genes for melting temperature curve analysis. The genes were ordered using the $p$-values of a one way ANOVA based on groups. Genes with the smallest $p$-values are presented first. Figures 3 through 5 represent characteristics of melt curve analysis protocols.

Figure 6a show eight employed control genes (Snord48, Snord47, Snord44, RNUU6-2. MiRTC1, miRTC2, and PPC1, PPC2). In Figure 6b, five miRNA genes (miR-184, miR-203, miR-124, miR-96 and miR-378) show clear separation. Gene miR-184 has the highest separation from the control gene. MiR-203 genes are hardly amplified in Sobya, while it is highly expressed in Pomegranate. For miR-373 gene, the control group is different from the other three treatment groups. For genes miR-124, miR96 and miR-378, Pomegranate is well separated from other three groups. In Figure 6c, for gene miR-301a, the control is separated from the other three groups. Additional miRNA genes are not 

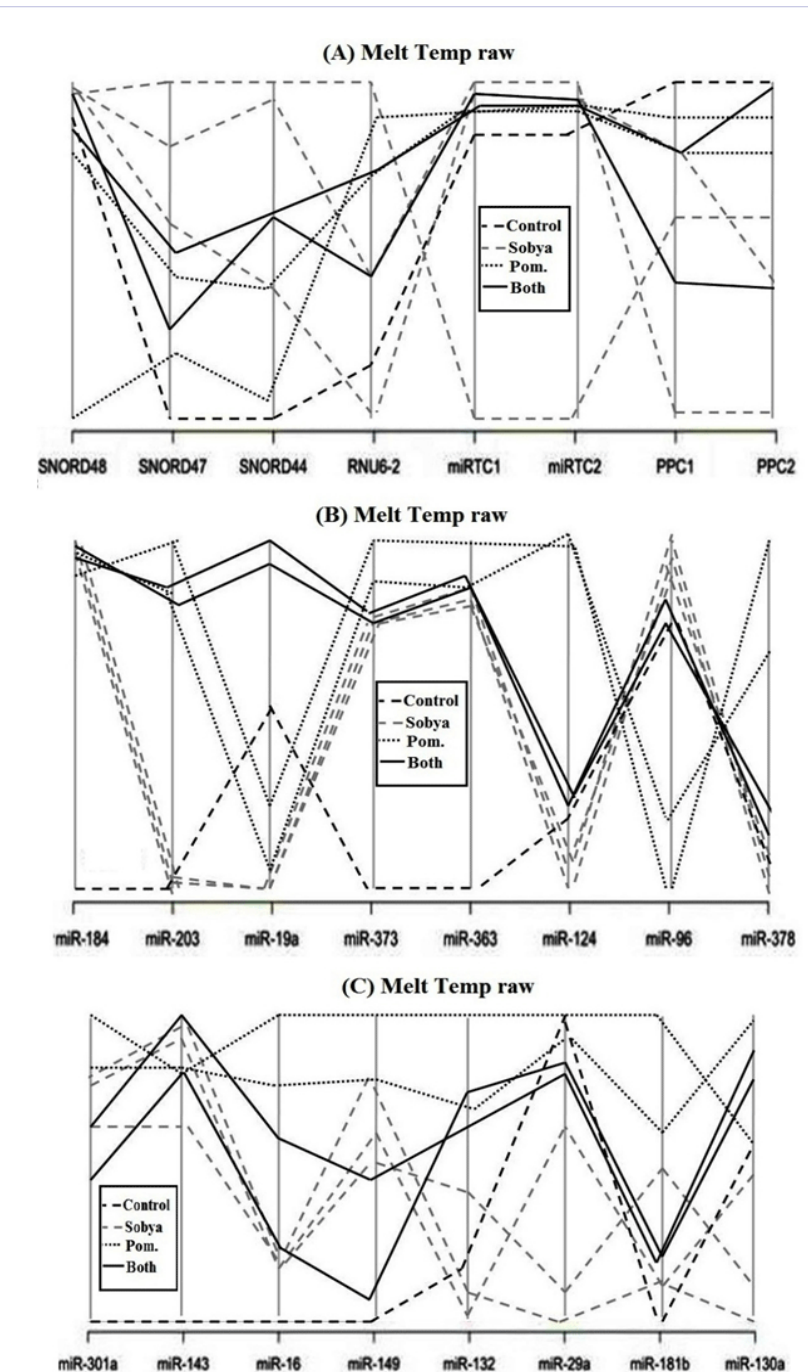

Figure 6 A: Change in fluorescence with increasing temperature is measured; as the temperature is increased from $650 \mathrm{C}$ is measured, the two strands of the amplicon separate to form a ssDNA, causing the fluorescent intercalating dye to dissociate from DNA and stop fluorescing. Figure 6 B: The shoulder in the curve between $80 \mathrm{oC}$ and $85 \mathrm{oC}$ suggests the presence of an intermediate state where the DNA is in both ds and ss configurations. Figure courtesy of Integrated DNA Technologies (www.idtdna.com);Downey N. (2014) Interpreting melt curves: An indicator, not a diagnosis. [Online] Coralville, Integrated DNA Technologies [Accessed May, 26, 2017]

shown, as their p-values are greater (less significant), and the graphs did not show any meaningful separations.

Bioinformatics analysis using the Target Scan algorithm [88] for up-regulated and down-regulated mRNAs genes is shown in Table 3. The program yielded 21 mRNA genes encoding different cell regulatory functions. The first 12 of these mRNAs were found with the DAVID program [89] to be active in the nucleus and related to transcriptional control of gene regulation. For down regulated miRNAs, the DAVID algorithm found the first four of these mRNAs to be clustered in cell cycle regulation categories. [90].

\section{Discussion}

Suitability of stool as a medium for developing a sensitive molecular biomarker screen

Stool represents a challenging environment, as it contains many substances that may not be consistently removed in PCR, in addition to the existence of certain inhibitors [91-94], which all must be removed for a successful PCR reaction. Our results $[56,75,78,95-97]$ and others [9] have shown that the presence of non-transformed RNA and other substances in stool do not interfere with measuring miRNA expressions, because of the use of suitable PCR primers, and the robustness of the real-time qPCR method. Besides, stool colonocytes contain much more miRNA and mRNA than that available in free circulation, as in plasma $[97,98]$, all factors that facilitate accurate and quantitative measurements.

\section{PCR amplification and the effect of Inhibitory Substances}

PCR has been used for miRNAs quantification because of its extreme sensitivity. This method, however, could lead to errors because of the presence of inhibiting substances, representing diverse compounds with different properties and mechanisms of action, which induce their effects by direct interaction with DNA that will be amplified, or through interference with the employed thermos table DNA polymerase. Agents that reduce $\mathrm{Mg} 2+$ availability, or interfere with the binding of $\mathrm{Mg} 2+$ to DNA polymerase could inhibit the PCR reaction [92]. Calcium ion is another inorganic inhibiting substance, although most PCR inhibitors are organic compounds (e.g., bile salts, sodium dodecyl sulphate, urea, phenol, ethanol, polysaccharides), as well as proteins (e.g., collagen, hemoglobin, immunoglobin G and proteinase) [99]. The existence of polysaccharides in stool could decrease the capacity to resuspend precipitated RNA, or disrupt the enzymatic reaction by mimicking the structure of nucleic acid. The DNA template of the PCR, as well as primers binding to DNA template can be inhibited by nucleases and other inhibitors, [93]. Remedial strategies for removal of inhibitors in stool, such as additional extraction steps, sephadex G-200 chromatography, heat treatment before the PCR, chloroform extraction, treatment with activated carbon, adding BSA, or dilution of sample, have been suggested [94]. We found the dilution method, in which the extracted ribonucleic acid (RNA) is diluted in the reaction mixture with distilled water or an isotonic buffer, to be the most practical method for preventing PCR inhibition using a commercially available diluent [100-102].

\section{Melting curve analysis (MCA)}

Microscale thermophoresis is a method that determines the stability, length, conformation and modifications of DNA and RNA. It relies on the directed movement of molecules in a temperature gradient that depends on surface characteristics of the molecule, such as size, charge and hydrophobicity. By measuring thermophoresis of nucleic acids over a temperature gradient, 
Table 3: Up-regulated and down-regulated target mRNA genes detected by a DAVID Bioinformatics algorithm.

Up-regulated target mRNA genes

BCL11B, CUGBP2, EGR3, DLHAP2, NUFIP2, KLF3, MECP2, ZNF532, APPLI1, NFIB, SMAD7, SNF1LK, ANKRD52, C17orf39, FAM13A1, GLT8D3,

KIAA0240, PCT, SOCS6, TNRC6B and UHRF1BP1.

Down-regulated target mRNA genes

TGFB1, CKS2, IGF2, KLK10, FLNA, CSE1L, CXCL3, DPEP1 AND GUCA2B

one finds clear melting transitions, and can resolve intermediate conformational states (Figure 3). These intermediate states are indicated by an additional peak in the thermophoretic signal preceding most melting transitions (Figure 3B) [73, 77-79] Agarose gel visualization is the gold standard for analyzing PCR products. Alternatively to reduce the number of gels needed to conform the presence of a single amplicon, "uMelt" melting curve prediction software (http://www.dna.utah/umelt/umelt.html) can be used to confirm that a single amplicon is generated by PCR [80]. This program predicts melt curves and their derivatives for qPCR-length amplicons, and is suited to test for multiple peaks in a single amplicon product.

...Because SYBR Green I dye has several limitations, including inhibition of PCR, preferential binding to CG-rich sequences and effects on MCA, two intercalating dyes SYTO-13 and SYTO-82 were tried and did not show these negative effects, and SYTO-82 demonstrated a 50-fold lower detection limit [81], as well as best combinations of time-to threshold $(\mathrm{Tt})$ and signal-to-noise ratio (SNR) [82]. To optimize performance of the buffer, a PCR mix supplemented with two additives, $1 \mathrm{M} 1$, 2-propanediol and 0.2 $\mathrm{M}$ trehalose, were shown to decrease Tm, efficiently neutralize
PCR inhibitors, and increase the robustness and performance of qPCR with short amplicons [83]. "UAnalyzeSM"is another web-based tool, similar to uMELT, for analyzing high-resolution melting PCR products' data, in which recursive nearest neighbor thermodynamic calculations are used to predict a melt curve. Using 14 amplicons of CYBB [cytochrome b-245 heavy chain, also known as cytochromae b(558) subunit], the main +/- standard deviation, the difference between experimental and predicted fluorescence at $50 \%$ helicity was $-0.04+/-0.480 \mathrm{C}$ [64].

In our study, we found the melt curve analysis to be a useful and an informative method because after the statistical analysis carried on our miRNA expression samples showed no preferential expression of any of the 88 miRNA genes, a melt curve analysis on the same samples found that we could distinguish 7 miRNA (miR-184, miR-203, miR-373, miR-124, miR-96, miR-373 and miR-301a), due to different separation melting profiles (Figure 6). Thus, we believe that it is imperatives for investigators to run this kind of analysis on samples that particularly may not show expression differences in their mRNA or miRNA studied genes, such as nutritional samples.

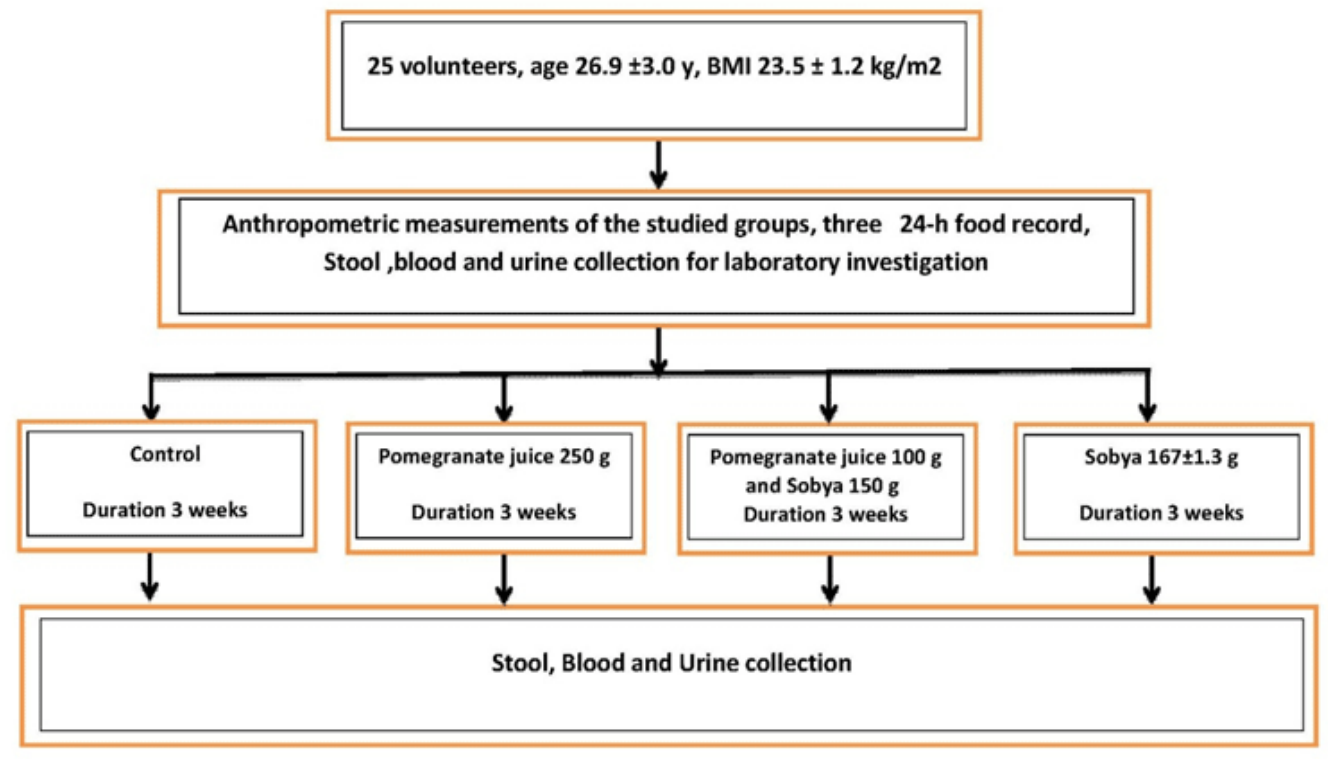

Chart 1. A chart illustrating the design of the randomized controlled trial.

Figure 7: A graphical representation of the parallel plot coordinates of the studies miRNA genes. The genes were ordered using the p-values of a one way ANOVA based on groups. Genes with the smallest p-values are presented first.

Figure 7a: show control genes. In

Figures7b, c: five miRNA genes show separation. 


\section{Bioinformatics methods to correlate seed miRNA Data with messenger (m) RNA Data}

To provide information about complex regulatory elements, we correlated miRNA results with our available mRNA data [1], as well as those data available in the open literature using computer model Target Scan $[88,89]$. The authenticity of functional miRNA/ mRNA target pair, once identified was validated by fulfilling four basic criteria: a) miRNA/mRNA target interaction can be verified, b) the predicted miRNA and mRNA target genes are co-expressed, c) a given miRNA must have a predictable effect on target protein expression, and d) miRNA-mediated regulation of target gene expression should equate to altered biological function. Bioinformatics showed 21 up regulated mRNA genes encoding different cell regulatory functions, and 12 of these mRNAs were found to be active in the nucleus and related to transcriptional control of gene regulation. For down-regulated miRNAs, four of the mRNAs appeared to be clustered in cell cycle regulation categories (Table 3) [56].

\section{Clinical Significance}

The clinical significance of the study presented above is that using melting temperatures for analyzing nutrient-gene data is a promising new approach for identifying key regulatory miRNA genes related to metabolites rich in polyphenols, Probiotic lactobacilli, or combinations of the two metabolites. Melt curve analysis is a powerful novel approach because after the statistical analysis carried on our miRNA samples produced negative gene expression (Cq) results, running melt curve analysis on the same samples identified 7 of the 88 miRNA genes imprinted on the highly sensitive focused PCR arrays ( $\sim 8 \%$ of the genes), and using parallel coordinates plots showed noticeable separation of melt curve profiles. Thus, we believe that it is imperatives for investigators to run this kind of MCA on nutrition samples that are mild in nature, and many not normally show significant differences in the expression of studied miRNA genes, particularly at the early stages $(0-1)$ of the cancer, before metastasis, so the cancer can be cured. The same analysis can also be envisioned for messenger mRNA amplifications, using mRNA arrays, and then using bioinformatics resources to correlate mRNA with miRNA data.

We are also planning to validate these initial results by carrying out additional miRNA nutrigenomic expression studies, with much more observations using PP, FS and their combinations, and collectively the obtained results would fully demonstrate the sensitivity/specificity of this powerful systemic molecular approach for analyzing nutrient-gene data.

Research efforts for the management of cancer are directed to identify new strategies for its early detection. Stable miRNAs are a new promising class of circulating biomarkers for cancer detection. However, the lack of consensus on data normalization, using relative PCR quantification methods, has affected the diagnostic potential of circulating miRNAs. There is thus a growing interest in techniques that allow for an absolute quantification of miRNAs, which would be more precise, and therefore more useful for early diagnosis of this curable cancer, if the cancer can be detected at the early premalignant disease stage (stage $0-1$ ).

Recently, digital PCR, mainly based on droplets generation, emerged as an affordable technology for the precise and absolute quantification of nucleic acids (103, 1`04). Given its reproducibility and reliability, as chip-digital absolute PCR quantification technique has becomes more established, it would be a robust tool for the quantitative assessment of miRNA copy number necessary for the diagnosis of the cancer, as well as for the identification and quantification of miRNAs in other biological samples such as circulating exosomes or protein complexes.

\section{Acknowledgments}

We express our deep thanks to those volunteers who participated in this research by completing a dietary questionnaire, and providing urine, blood and stool samples for the study. We thank Dr. Clark D. Jeffries at Renaissance Computing Institute, University of North Carolina at Chapel Hill for his bioinformatics analysis, Funds for this research were provided by NIH Grant 1R43CA144823, and by GEM Tox Labs operating funds.

\section{References}

1. Ahmed FE, Vos P, iJames S, Lysle DT, Allison RR, Flake G, Naziri W, et al. Transcriptomic molecular markers for screening human colon cancer in stool and tissue. Cancer Genom Proteom. 2007;4(1).1-20.

2. Ahmed FE. Microarray RNA transcriptional profiling: Part I. Platforms, experimental design and standardization. Exp Rev Mol Diag. 2006;6(4):535-550.

3. Ahmed FE. Microarray RNA transcriptional profiling: Part II. Analytical considerations and annotations. Exp Rev Mol Diag. 2006;6(5):703-715.

4. Lee RC, Feinbaum RL and Ambros V. The C. elegans heterochronic gene lin-4 encodes a small RNAs with antisense complimentarity to lin-14. Cell. 1993;75(5).843-854.

5. Kozomara A and Griffithis JS. miRBase. annotating high confidence microRNAs using deep sequencing data. Nucleic Acids Res. 2014;42(Database issue).D68-73. doi. 10.1093/nar/gkt1181

6. Lund $E$ and Dahlberg JE. Substrate selectivity of exportin 5 and Dicer in the biogenesis of microRNAs. Cold Spring Harb Symp Quant Biol. 2006;71.59-66.

7. Lim LP, Lau NC, Garrett-Engele P, Grimson A, Schelter JM, Castle J, Bartel DP A, et al. Microarray analysis shows that some microRNAs downregulate large numbers of target mRNAs. Nature. 2005;433(7027).769-773.

8. De Caterina R and Madonna R. Nutrients and gene expression. World Rev Nutr Diet. 2004;93.99-133.

9. Link A, Balaguer F, Shen Y, Nagasaka T, Lozano JJ, Boland CR, Goel A., et al. Fecal MicroRNAs as novel biomarkers for colon cancer screening. Cancer Epidemiol Biomarkers Prev. 2010;19(7).17661774. doi. 10.1158/1055-9965

10. Biomarkers Definition Working Group. Biomarkers and surrogate endpoints: preferred definitions and conceptual framework. Clin Pharmacol Therapeutics. 2001;69(3):89-95. 
11. Strimbu K and Tavel JA. What are biomarkers?. Curr Opin HIV AIDS. 2010;5(6).463-466

12. Roever L. Endpoints in Clinical Trials: Advantages and Milestones. Evidence Based Medicine and Practice. 2016;1:2. doi: 10.4172/ ebmp.1000e111

13. Endpoints: How the Results of Clinical Trials are Measured. 2004.

14. Clinical endpoints: Principles of Translational Science in Medicine. 2nd Ed. 2015.

15. Bautista RR, Gomez AO, Miranda AH, Dehesa AZ, Villarreal-Gmza C, Avila-Moreno F, Arrieta, et al. Long-coding RNAsi: Implications in targeted diagnosis, prognosis, and improved therapeutic strategies in human non- and triple-negative breast cancer. Clin Epigenet. 2018;10(88). doi: 10.1186/s13148-018-0514-z

16. Klasić M, Markulin D, Vojta A, Samaržija I, Biruš I, Dobrinić P, Ventham NT,et al. Promoter methylation of the MGAT3 and BACH2 genes correlates with the composition of the immunoglobulin G glycome in inflammatory bowel disease. Clin Epigenetics. 2018;10(75):1-14.

17. Research (CBER). Guidance for industry: Clinical trial endpoints for the approval and of cancer drugs and biologics. 2007.

18. Werner RM and Pearson TA. LDL-Cholestrol. A risk factor for Coronary Artery Disease from Epidemiology to Clin Trials. Canad J Cardiology. 1998;14 Suppl B.3B-10B.

19. Bikdeli B, Pumanithinot N, Akram Y, Lee L, Desai NR, Ross J, Krumholz HM, et al. Two decades of cardiovascular trials with primary surrogate endpoints 1990-2011. J Am Heart Assoc. 2017;6(3): e005285. doi: 10.1161/JAHA.116.005285

20. Waladkhani AR. Conducting clinical trials: A theoretical and practical guide. 2008.

21. Wenting andSargentDJ.Statisticsand ClinicalTrials: Clinical Radiation Oncology. 3rd Ed. 2012.

22. Hussein L, Abdl-Rehim EA, Afifi AMR, El-Arab AE and Labib E Effectiveness of aprictos (Prunus ameniea) juice and lactic acid fermented sobya on plasma levels of lipid profile parameters and total homocysteine among Egyptian adults. Food Nutr Sci. 2014; 5(22):11

23. World Health Organization (WHO). Cardiovascular Diseases (CVDs). WHO Fact Sheet No. 317, Geneva. 2011.

24. Bernedetti S, Catalani S, Palma F and Trari FC. The antioxidant protection of CELLFOOD $®$ against oxidatice change in vitro Food Chem Toxicol. 2011;49(9).2292-2298. doi. 10.1016/j. fct.2011.06.029

25. Bengmark S. Advanced glycation and lipoxidation end products-amplifiers of inflammation. the role of food. J Parenter Enteral Nutr. 2007;31(5).430-440

26. Gouda M, Moustafa A, Hussein L, and Hamza M. Three week dietary intervention using apricots, pomegranate juice or/and fermented sour sobya and impact on biomarkers of antioxidative activity, oxidative stress and erythrocytic glutathione transferase activity among adults. Nutritional J. 2016;15.52. doi. 10.1186/s12937-0160173-x

27. Esmaillzadeh A, Tahbaz F, Gaieni I, Alavi-Majd H. Cholestrollowering effect of concentrated pomeg- ranate juice consumption in Type II diabetic patients with hyperlipidemia. Int J Vit Nutr Res. 2006;76(3).147-151
28. Zhuang G, Liu XM, Zhang QX, Tian F W. Research advances with regards to clinical outcome and potential mechanisms of the cholestrol-lowering effects of probiotics. Clinical Lipidology. 2012;7(5).501-50.

29. van Baarlen P, Troost F, van der Meer C, Hooiveld G. Human mucosal in vivo transcriptome responses to three lactobacilli indicate how probiotics may modulate human cellular pathways. Proc Natl Acad Sci USA.2011;108(Suppl 1).4562-4569.

30. Richards AL, Burns MB, Alazizi A, Barreiro LB, Roger Pique-Regi, Ran Blekhman. Genetic and transcriptional analysis of human host response to healthy gut microbiota. MSystems. 2016;1(4).e0006716. doi.10.1128/mSystems

31. Noori-Daloii MR and Nejatizdeh A. Nutritional transcriptomics: An Overview. Eds Debasis Bagehi, Anand Swarooop and Manashi Bagehi. 2015:545-556.

32. Luu-The V, Paquet N, Calvo E, Cumps J. Improved real-time RT-PCR measurements using second derivative calculation and double correction. BioTechniques. 2005;38(2).287-293.

33. Livak K J, Schmittgen T D. Analysis of relative gene expression data using real-time quantitative PCR and thwe $2-\Delta \Delta \mathrm{Ct}$ method. Methods. 2001;25(4).402-408.

34. Reinhart BJ, Slack FJ, Basson M, Pasquinell AE, Bettinger JC, Rougvie $\mathrm{AE}$, et al. RNA regulates developmental timing in Caenorhabditis elegans. Nature. 2000;403(6772).901-906.

35. Tellman G. The E-method: a highly accurate technique for geneexpression analysis. NatureMethods. 2006.

36. http://www.lightcycler-online.com/lc_sys/soft_nd.htm\#quant.

37. LightCycler. Roche Moecular Biochemicals. Manneheim, Germany. 2001:64-79.

38. Huang da W, Sherman BT, Lempicki RA. Systematic and integrative analysis of large gene lists using DAVID bioinformatics resources. Nat Protocol. 2009;4(1).44-57. doi. 10.1038/nprot.2008.211

39. Ririe KM, Rasmussen RP and Wittwer CT. Product determination by analysis of DNA melting curves during the polymerase chain reaction. Anal Biochem. 1997;245(2).154-160

40. Xu P, Guo M and Hay BA. MicroRNAs and the regulation of cell death. Trend Genet. 2004;20(12).617-624.

41. Malumbres M. miRNAs and cancer. an epigenetics view. Mol Aspects Med. 2013;34(4).863-874. doi. 10.1016/j.mam.2012.06.005

42. Zhao Y, Ransom JF, Li A, Vedantham V, von Drehle M, Muth AN, et al. Dysregulation of cardiogenesis, cardiac conduction, and cell cycle in mice lacking miRNA-1-2. Cell. 2007;129(2).303-317.

43. Phua YL, Chu JY, Marrone AK, Bodnar AJ, Sims-Lucas S, Ho J. Renal stromal miRNAs is required for normal nephrogenesis and glomerular mesangial survival. Physiological Reports. 2015;3(10).pii.e12537. doi.10.14814/phy2.12537

44. Maes OC, Chertkow HM, Wang E and Schipper HM. MicroRNA. Implications for Alzheimer Disease and other Human CNS Disorders. Current Genomics. 2009;10(3).154-168. doi. $10.2174 / 138920209788185252$

45. Li J, Li J, Liu X, Qin S, Guan Y, Liu Y, et al. MicroRNA expression profile and functional analysis reveal that miR-382 is a critical novel gene of alcohol addiction. EMBO Mol Med. 2013;5(9):1402-1414. doi: 10.1002/emmm.201201900 
46. Romao JM, Jin W, Dodson MV, Hausman GJ, Moore SS, Guan LL. MicroRNA regulation in mammalian adipogenesis. Exp Biol Med. 2011;236(9):997-1004. doi: 10.1258/ebm.2011.01110

47. Mencía A, Modamio-Høybjør S, Redshaw N, Morín M, MayoMerino F, Olavarrieta $\mathrm{L}$, et al. Mutations in the seed region of human miR-96 are responsible for nonsyndromic progressive hearing loss. Nat Genet. 2009;41(5):609-613. doi: 10.1038/ng.35 5

48. Hughes AE, Bradley DT, Campbell M, Lechner, Dash DP, Simpson DA, et al. Mutation Altering the miR-184 Seed Region Causes Familial Keratoconus with Cataract. Am J Hum Genet. 2011;89(5):628-633. doi: 10.1016/j.ajhg.2011.09.014

49. de Pontual L, Yao E, Callier P, Faivre L, Drouin V, Cariou S, et al. Germline deletion of the miR-7-92 cluster causes kel skeletal and growth defects in humans. Nat. Genet. 2011;43(10):1026-1030. doi: 10.1038/ng.915

50. Tuddenham L, Jung JS, Chane-Woon-Ming B, Dölken L, Pfeffer S. Small RNA deep sequencing identifies microRNAs and other small noncoding RNAs from human herpesvirus 6B. J Virol. 2012;86(3):1638-1649. doi: 10.1128/JVI.0591111

51. Lu M, Zhang Q Deng M, Guo Y, Wei Gao, Qinghua Cui, et al. An analysis of human microRNA and disease association. Plos One. 2008;3(10) :e3420.

52. Gregory RI and Shiekhattar R. MicroRNA biogenesis and cancer. Cancer Res. 2005;65(9):3509-3512.

53. Calin GA, Ferracin M, Cimmino A, Dileva G, Shimizu M, Wojcik SE, Iorio $\mathrm{MV}$, et al. A microRNA signature associated with prognosis and progression in chronic lymphocytic leukemia. N Eng J Med. 2005;353(17):1793-1801.

54. Chang-Zheng C. MicroRNAs as oncogenes and tumor supressors. $\mathrm{N}$ Eng J Med. 2005;353(17):1768-1771.

55. Calin GA, Sevignai C, Dumitru CD, Hyslop T. Human microRNA genes are frequently located at fragile sites and genomic regions involved in cancers. Proc Natl Acad Sci USA. 2004;101(9):2999-3004.

56. Schepler T, Reinert JT, Oslenfeld MS, Christensen LL, Silahtaroglu AN, Dyrskjøt L, Wiuf C, et al. Diagnostic and prognostic microRNAs in Stage II colon cancer. Cancer Res. 2008;68(15):6416-6424. doi:10.1158/0008-5472.CAN-07-6110

57. Schetter AJ, Leung SY, Sohn JJ, Zanetti KA, Elise D. Bowman, Nozomu Yanaihara, Siu Tsan Yuen, et al. MicroRNA expression profile associated with progression and therapeutic outcome in colon adenocarcinoma. J Am Med Assoc. 2008;299(4):425-436. doi: 10.1001/jama.299.4.425

58. Calin GA and Croce CM. MicroRNA signatures in human cancers. Nat Rev Cancer. 2006;6(11):857-866.

59. Ahmed FE, Ahmed NC, Vos PW, Bonnerup C, Atkins JN, Casey M, Nuovo GJ, et al. Diagnostic microRNA markers to screen for sporadic human colon cancer in stool. I. Proof of principle. Cancer Genom Proteom. 2013;10(3).93-113.

60. Varga A and Delano J. Effect of amplicon size, melt rate, and dye translocation. J Virol Meth. 2006;132(1-2):146-153.

61. Mendes RE, Kiyota KA, Monteiro J, Castanheira M, Andrade SS, Gales $\mathrm{AC}$, et al. Rapid detection and identification of metallo- $\beta$-Lactamase- encoding genes by multiplex real-time PCR asay and melt curve analysis. J Clin Microbiol. 2007;45(2):544-547.

62. Guion CE, Ochoa TJ, Walker CM, Barletta F, Cleary TG. Detection of diarrheagenic Escerichia coli by use of melting-curve analysis and real-time multiplex PCR. J Clin Microbiol. 2008;46(5):1752-1757. doi: 10.1128/JCM.02341-07

63. Winder L, Phillips C, Richards N, Ochoa-Corona F, Hardwick S, Vink CJ, et al. Evaluation of DNA melting analysis as a tool for species identification. Meth Ecology Evol. 2011;2(3):312-320.

64. Von Keyserling H, Bergmann T, Wiesel M, Kaufmann AM. The use of melting curves as a novel approach for Validation of realtime PCR instruments. BioTechniques. 2011;51(3):179-184. doi: 10.2144/000113735

65. Bohling SD, Wittwer CT, King TC, Elenitoba-Johnson KS. Fluorescence melting curve analysis for the detection of the bcl-1/JH translocation in mantle cell lymphoma. Lab Invest. 1999;79(3):337-345.

66. de Fdippes FF, Wang J-W and Weigel D: MIGS: miRNA-induced gene silencing. The Plant J 70(3): 541-547, 2011.

67. Dwight Z, Palais R and Wittwer CT. $\mu$ MELT:prediction of highresolution melting curves and dynamic melting profiles of PCR products in a rich web application. Bioinformatics. 2011;27(7):10191020. doi: 10.1093/bioinformatics/btr065

68. Downey N. Interpreting melt curves. An indicator, not a diagnosis.

69. Farrar JS, Reed GH, Wittwer CT. High-resolution melting curve analysis for molecular diagnosis. In Molecular Diagnostics. 2014;229-245. doi. 10.1016/B978-0-12-374537-8.00015-8

70. Krypuy M, Ahmed AA, Etemadmoghadam D, DeFazio A, Fox SB, Brenton JD, et al. High resolution melting for mutation scanning of TP53 exon 5-8. BMC Cancer. 2007;7:168.

71. Pasay C, Arlian L, Morgan M, et al. High -resolution melt analysis for the detection of a mutation associated with permethrin resistance in a population of scabies mites. Med Vet Entomol. 2008; 22(1):82-88.

72. Montgomery JL, Sanford LN, Twitter CT. High-resolution DNA melting analysis in clinical research and diagnosis. Expert Rev Mol Diagn. 2010;10(2):219-240. doi: 10.1586/erm.09.84

73. Ansevin AT, Vizard DL, Brown BW and McConathy J. Highresolution thermal denaturation of DNA. I. Theoretical and practical considerations for the resolution of thermal subtransitions. Biopolymers. 1976;15(1):153-174. doi:10.1002/ bip.1976.360150111

74. Ririe KM, Rasmussen RP and Wittwer C T. Product differentiation by analysis of DNA during melt curves during the polymetrase chain reaction. Anal Biochem. 1997;245(2):154-160.

75. Wittwer CT. High-resolution DNA melting analysis: Advancements and limitations. Hum Mutat. 2009;30(6):857-9. doi: 10.1002/hum u.20951

76. Ahmed FE, Hussein LA, Gouda MM, Vos PW and Ahmed NC. Melt Curve Analysis in Interpretation of Nutrigenomics' MicroRNA Expression Data. Trends Res. 2018;1 (1):1-10.

77. Ahmed FE, Gouda MM, Hussein LA, Ahmed NC, Vos PW, Mohammad M. Role of Melt Curve Analysis in Interpretation of Nutrigenomics' MicroRNA Expression Data. Cancer Genom. Proteom. 2017;14(6):469-481.

78. Freier SM, Kierzek R, Jaeger JA, Sugimoto N M H Caruthers, T Neilson, D H Turner, et al. Improved free-energy parameters for prefictions 
of RNA duplex stability. Proc Natl Acad Sci USA. 1986;83(24):93739377.

79. Lay MJ and Wittwer CT. Real-time fluorescence genotyping of factor V Leiden during rapid-cycle PCR. Clin Chem. 1997;43(12):22622267.

80. Wienken C J, Baaske P, Duhr S, Braun D. Thermophoretic melting curve quantify the conformation and stability of RNA and DNA. Nucleic Acids Res. 2011;39(8):e52. doi: 10.1093/nar/gkr035

81. Dwight Z, Palais R and Wittwer CT. $\mu$ MELT:prediction of highresolution melting curves and dynamic melting profiles of PCR products in a rich web application. Bioinformatics. 2011;27(7):10191020. doi: $10.1093 /$ bioinformatics/btr065

82. Gudnason H, Dufva M, Bang D D, Wolff A. Comparison of multiple DNA dyes for real-time PCR:effects of dye concentration and sequence composition on DNA amplification and melting temperature. Nucleic Acids Res. 2007;35(19):e127. doi: 10.1093/nar/gkm671

83. Oscorbin IP, Belousova EA, Zakabunin AI, Boyarskikh UA and Filipenko M L. Comparison of fluorescent intercalating dyes for quantitative loop-mediated isothermal amplification. BioTechniques. 2016;61(1):20-25. doi: 10.2144/000114432

84. Horakova H, Polakovicova I, Shaik GM, Eitler J, Bugajev V, Draberova L, Draber P, et al. 1,2-propanediol-trehalose mixture as a potent quantitative real-time PCR enhancer. MBC Biotechnol. 2011;11:41

85. Venables WN and Ripley BD (Eds.). Modern and Applied Stastistics. Fourth Edition. Springer, New York. 2002.

86. R Core Team R. A language and environment for statistical computing. R Foundation for Statistical Computing, Vienna, Australia. 2015.

87. Ahmed F E. Statistical Analysis of microRNA as markers for Screening of Colon Cancer. Biostatistics and Biometrics J (BBOAJ). 2018;6(4):14. doi: 10.19080/BBOAJ.2018.06.555691

88. Benjamini $\mathrm{Y}$ and Yekutieli D. The controil of the false discovery rate in multiple testing under dependency. Annals Stat. 2001;29(4).11651188.

89. Huang da W, Sherman BT, Lempicki RA. Systematic and integrative analysis of large gene lists using DAVID bioinformatics resources. Nat Protocol. 2009;4(1).44-57. doi. 10.1038/nprot.2008.211

90. Thompson S M, Ufkin JA, Sathyanarayana M L, Liaw P, et al. Common features of micro RNA target prediction tools. Front Genet. 2014; 5:23. doi: $10.3389 /$ fgene.2014.00023

91. Al-Soud WA and Radstrom P. Capacity of nine thermostable DNA polymerases to mediateDNA amplification in the presence of PCRinhibiting samples. Appl Env Microbiol. 1998;64(10).3748-3753.
92. Wilson I G. Inhibition and facilitation of nucleic acid amplification. Appl Env Microbiol. 1997;63(10).3741-3751.

93. Montiero I, Bonnemaison D, Vekris A, Petry KG, J Bonnet, R Vidal, et al. Comples polysaccharides as PCR inhibitors in feces. Heliobacter pylori model. J Clin Microbiol. 1997;35(4):995-998.

94. Schrader C, Schielke A, Ellerbroek L and Johne R. PCR inhibitors- occurrence, properties and removal. J Appl Microbiol. 2012;113(5).1014-1026. doi. 10.1111/j.1365-2672.2012.05384.x.

95. Ahmed FE, Ahmed NC, Vos P, Bonnerup C, Atkins JN, Casey M. Diagnostic microRNA markers to screen for sporadic human colon cancer in blood. Cancer Genom Proteom. 2012;9(4).179-192.

96. Ahmed F E, Ahmed N C, Gouda M and Bonnerup C. MicroRNAs as Molecular Markers for Screening of Colon Cancer. Case Rep Surg Invasive Proced. 2017;1(2):14-17.

97. Ahmed F E, Ahmed N C, Gouda M and Vos P W. MiRNAs for the Diagnostic Screening of Early Stages of Colon Cancer in Stool or Blood. Surgical Case Reports and Reviewss. 2017;1(1):1-19. doi: 10.a5761/SCRR.1000103

98. Ahmed F E, Vos P W, Ijames S, Lysle DT, Flake G, Sinar DR, Naziri W, et al. Standardization for transceiptomic molecular markers to screen human colon cancer. Cancer Genom Proteom. 2007; 4( 6): 419-431.

99. Davidson LA, Lupton JR, Miskovsky E, Fields AP. Quantification of human intestinal gene expression profiling using exfoliated colonocytes. a pilot study. Biomarkers. 2003;8(1).51-61.

100. Rådström P, Knutsson R, Wolffs P, Lovenklev M. Pre-PCR processing. strategies to generate PCR-compatible samples. Mol Biotechnol. 2004;26(2).133-146.

101. Scipioni A, Mauroy A, Ziant D, Saegerman C et al. A SYBR Green RTPCR assay in single tube to detect human and bovine noroviruses and control for inhibition. Virology J. 2008;5.94. doi. 10.1186/1743422X-5-94

102. Ahmed F E. MicroRNAs as Molecular Markers for Colon Cancer Diagnostic Screening in Stool \& Blood. Int Med Rev . 2017;9:124. doi: $10.3390 /$ cancers 9090124

103. AhmedFE.UseofChip-BasedPCRfor3DAbsoluteDigitalQuantification of microRNAs Molecules for The Non-Invasive Diagnostic Screening of Human Colon Cancer in Stool. Integrative Care Sci Therapeutics. 2018;5(2):1-1.

104. Ahmed, F E, Gouda M M, Ahmed N C. Chip-Based Digital PCR for Absolute Quantification of Colon Cancer miRNAs with 3D digital, chip-based PCR. Arch Oncol Cancer Ther. 2018;1(1):1-24. 